\title{
A novel chalcone derivative has antitumor activity in melanoma by inducing DNA damage through the upregulation of ROS products
}

Keke $\mathrm{Li}^{1,2,3+}$, Shuang Zhao ${ }^{1,2,3+}$, Jing Long ${ }^{1,2,3 \dagger}$, Juan Su, ${ }^{1,2,3}$, Lisha Wu ${ }^{1,2,3}$, Juan Tao ${ }^{4}$, Jianda Zhou ${ }^{5}$, JiangLin Zhang ${ }^{1,2,3^{*}}$, Xiang Chen ${ }^{1,2,3^{*}}$ and Cong Peng ${ }^{1,2,3^{*}}$ (D)

\begin{abstract}
Background: Melanoma is one of the most aggressive tumors with the remarkable characteristic of resistance to traditional chemotherapy and radiotherapy. Although targeted therapy and immunotherapy benefit advanced melanoma patient treatment, BRAFi (BRAF inhibitor) resistance and the lower response rates or severe side effects of immunotherapy have been observed, therefore, it is necessary to develop novel inhibitors for melanoma treatment.

Methods: We detected the cell proliferation of lj-1-59 in different melanoma cells by CCK 8 and colony formation assay. To further explore the mechanisms of lj-1-59 in melanoma, we performed RNA sequencing to discover the pathway of differential gene enrichment. Western blot and Q-RT-PCR were confirmed to study the function of lj-1-59 in melanoma.
\end{abstract}

Results: We found that lj-1-59 inhibits melanoma cell proliferation in vitro and in vivo, induces cell cycle arrest at the G2/M phase and promotes apoptosis in melanoma cell lines. Furthermore, RNA-Seq was performed to study alterations in gene expression profiles after treatment with lj-1-59 in melanoma cells, revealing that this compound regulates various pathways, such as DNA replication, P53, apoptosis and the cell cycle. Additionally, we validated the effect of lj-1-59 on key gene expression alterations by Q-RT-PCR. Our findings showed that lj-1-59 significantly increases ROS (reactive oxygen species) products, leading to DNA toxicity in melanoma cell lines. Moreover, lj-1-59 increases ROS levels in BRAFi -resistant melanoma cells, leading to DNA damage, which caused G2/M phase arrest and apoptosis.

Conclusions: Taken together, we found that lj-1-59 treatment inhibits melanoma cell growth by inducing apoptosis and DNA damage through increased ROS levels, suggesting that this compound is a potential therapeutic drug for melanoma treatment.

Keywords: Chalcone, DNA damage, Melanoma, P53, ROS (reactive oxygen species)

\section{Background}

Cutaneous melanoma is the most aggressive type of skin cancer $[1,2]$, and its incidence and mortality is increasing

\footnotetext{
*Correspondence: leozj11010@126.com; chenxiangck@126.com; pengcongxy@csu.edu

${ }^{\dagger}$ Keke Li, Shuang Zhao and Jing Long contributed equally to this work ${ }^{1}$ The Department of Dermatology, Xiangya Hospital, Central South University, 87 Xiangya Road, Changsha, Hunan, China

Full list of author information is available at the end of the article
}

annually worldwide [3, 4]. In 2017 , there were 87,110 patients diagnosed with melanoma, and 9730 cases were proposed deaths from malignant melanoma [5]. Although primary melanoma has been cured by surgical therapy, melanoma cells from the primary tumor break through the basement membrane in the early stage and invade the lymphatics or vasculature, leading to the formation of metastatic lesions in distant organs, including the lungs, brain and liver [6], resulting in a 5-year

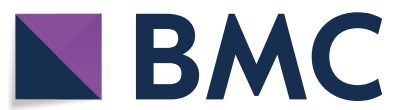

(c) The Author(s) 2020. This article is licensed under a Creative Commons Attribution 4.0 International License, which permits use, sharing, adaptation, distribution and reproduction in any medium or format, as long as you give appropriate credit to the original author(s) and the source, provide a link to the Creative Commons licence, and indicate if changes were made. The images or other third party material in this article are included in the article's Creative Commons licence, unless indicated otherwise in a credit line to the material. If material is not included in the article's Creative Commons licence and your intended use is not permitted by statutory regulation or exceeds the permitted use, you will need to obtain permission directly from the copyright holder. To view a copy of this licence, visit http://creativecommons.org/licenses/by/4.0/. The Creative Commons Public Domain Dedication waiver (http://creativecommons.org/publicdomain/zero/1.0/) applies to the data made available in this article, unless otherwise stated in a credit line to the data. 
survival rate of less than $10 \%$ [7]. The risk factors of melanoma development involve genetic and environmental effects [8]. NGS (next generation sequencing) studies identified somatic mutations that generate a landscape of melanoma somatic mutations, including $B R A F, N R A S$, NF1, PTEN, CDKN2A and TP53, as driving mutations or potential tumor suppressors and oncogenes [9].

The BRAFV600E mutation, as a frequent somatic mutation, occurs in approximately $60 \%$ of melanomas, causing the constitutive activation of the mitogen-activated protein kinase (MAPK) pathway [10]. Therefore, the BRAFV600E mutation acts as a pivotal oncogenic driver gene in melanoma, leading to the development of targeted BRAF kinase inhibitors. PLX4720 has been developed as a BRAFV600E inhibitor versus BRAF wildtype tumors in vivo based on a structural analog, which was approved for the treatment of advanced metastatic melanoma patients with BRAFV600E mutation expression [11]. MEK inhibitors, such as trametinib, have been approved for the treatment of advanced melanoma patients carrying the BRAF mutation [12]. In a clinical trial, a $22 \%$ response and 4.8-month median progressionfree survival were observed in patients with metastatic melanoma expressing BRAFV600E/K after trametinib therapy compared with chemotherapy [13]. Although BRAFi significantly benefits clinical responses and promotes advanced melanoma patient survival, drug resistance and relapse can develop over several months of treatment [14].

The development of novel immunotherapies, such as anti-CTLA4 and anti-PD-1, has significantly improved melanoma patient outcomes $[15,16]$. CTLA-4 is an immune checkpoint receptor [17] and the first receptor targeted by a clinical therapeutic antibody (ipilimumab) approved by the FDA in 2011 [18]. PD-1 is another T cell inhibitory receptor that exerts immune suppression through PD-1 ligand (PD-L1) [19]. Blockade of PD-1 or PD-L1 with therapeutic antibodies benefits the activation of tumor antigen-specific $T$ cells but does not affect autoreactive $\mathrm{T}$ cells. These recent immunotherapies dramatically reduce tumor burden and benefit advanced melanoma patient overall survival [20]. However, the clinical response is approximately $20-30 \%$ [21], and at the same time, these therapies have some fatal side effects. Therefore, it is necessary to develop novel inhibitors for melanoma treatment.

Chalcone is one of the numerous natural compounds that is widely found in fruits, vegetables and tea [22, 23]. Chalcone has various biological activities, including antiinflammatory, antibacterial and antioxidant activities [24, 25]. Chalcone has been shown to have a skeletal structure for antitumor treatment, such as lung cancer, colorectal cancer, liver cancer and breast cancer [26-28]. Therefore, chalcone derivatives have been widely studied for antitumor pharmacological activities.

In this study, we found a chalcone derivative, lj-1-59 ((E)-1-(3-hydroxyphenyl)-3-(3,4,5-trimethoxyphenyl) prop-2-en-1-one) synthesized from 3,4,5-trimethoxybenzaldehyde and 3'-hydroxyacetophenone through ClaisenSchmidt reaction in our lab, significantly inhibits melanoma cell growth in vitro and in vivo. Furthermore, this compound significantly increases ROS products as a consequence of induced apoptosis and G2/M phase arrest through ROS-mediated DNA damage, resulting in the activation of ATM, ATR and H2AX, suggesting that this compound is a promising medicine for melanoma treatment.

\section{Methods}

\section{Chemicals}

lj-1-59((E)-1-(3-hydroxyphenyl)-3-(3,4,5-trimethoxyphenyl)prop-2-en-1-one) (Fig. 1a) was synthesized as follow: To a cold solution of $\mathrm{NaOMe}(216 \mathrm{mg})$ in $\mathrm{MeOH}(4 \mathrm{~mL})$ was added 3,4,5-trimethoxybenzaldehyde (200 mg, $1 \mathrm{mmol}$ ) and 3'-hydroxyacetophenone (139 $\mathrm{mg}, 1 \mathrm{mmol}$ ), stirred for $48 \mathrm{~h}$ at room temperature. Concentrated, added $3 \mathrm{~mL} \mathrm{H}_{2} \mathrm{O}$, washed with $\mathrm{Et}_{2} \mathrm{O}$ three times, added $12 \mathrm{~N} \mathrm{HCl}$ until $\mathrm{pH}=1$. Extracted with EtOAc three times, The organic extracts was washed with brine, dried over $\mathrm{Na}_{2} \mathrm{SO}_{4}$, filtered, and concentrated, recrystallized from $\mathrm{EtOH} / \mathrm{H}_{2} \mathrm{O}$ to get the product $(236 \mathrm{mg}, 75 \%) .{ }^{1} \mathrm{H}$ NMR $(500 \mathrm{MHz}, \mathrm{DMSO}) \delta 9.82(\mathrm{~s}, 1 \mathrm{H}), 7.83(\mathrm{~d}, J=15.6 \mathrm{~Hz}$, $1 \mathrm{H}), 7.72-7.60(\mathrm{~m}, 2 \mathrm{H}), 7.48-7.46(\mathrm{~m}, 1 \mathrm{H}), 7.39(\mathrm{t}$, $J=7.9 \mathrm{~Hz}, 1 \mathrm{H}), 7.23(\mathrm{~s}, 2 \mathrm{H}), 7.07(\mathrm{dd}, J=8.1,1.3 \mathrm{~Hz}, 1 \mathrm{H})$, 3.87 (s, 6H), $3.72(\mathrm{~s}, 3 \mathrm{H}) ;{ }^{13} \mathrm{C}$ NMR $(125 \mathrm{MHz}, \mathrm{DMSO})$ $\delta$ 189.6, 158.2, 153.6, 144.8, 140.2, 139.6, 130.7, 130.2, $121.9,120.7,120.1,115.1,107.0,60.6,56.6 .1 j-1-59$ was diluted to $50 \mathrm{mM}$ in DMSO and stored at $-20^{\circ} \mathrm{C}$.

\section{Cell lines and culture}

The human melanoma cell lines A375, SK-Mel-5, and SKMel-28 were purchased from the ATCC (Manassas, VA, USA), and the BRAFi-resistant cell line, called RA, was generated as described in a previous study $[9,29]$. JB6 mouse skin epidermal cell line, BJ human skin fibroblast cell line,PIG1 human melanocyte cell line, H9C2 human heart myoblast cell line were purchased from the ATCC. Both cell lines were cultured at $37{ }^{\circ} \mathrm{C}$ in DMEM $(10 \%$ FBS, $1 \%$ penicillin-streptomycin). RA cells were maintained in culture with $2 \mu \mathrm{M}$ vemurafenib (PLX4032), and the drug was removed 1 week before use. 

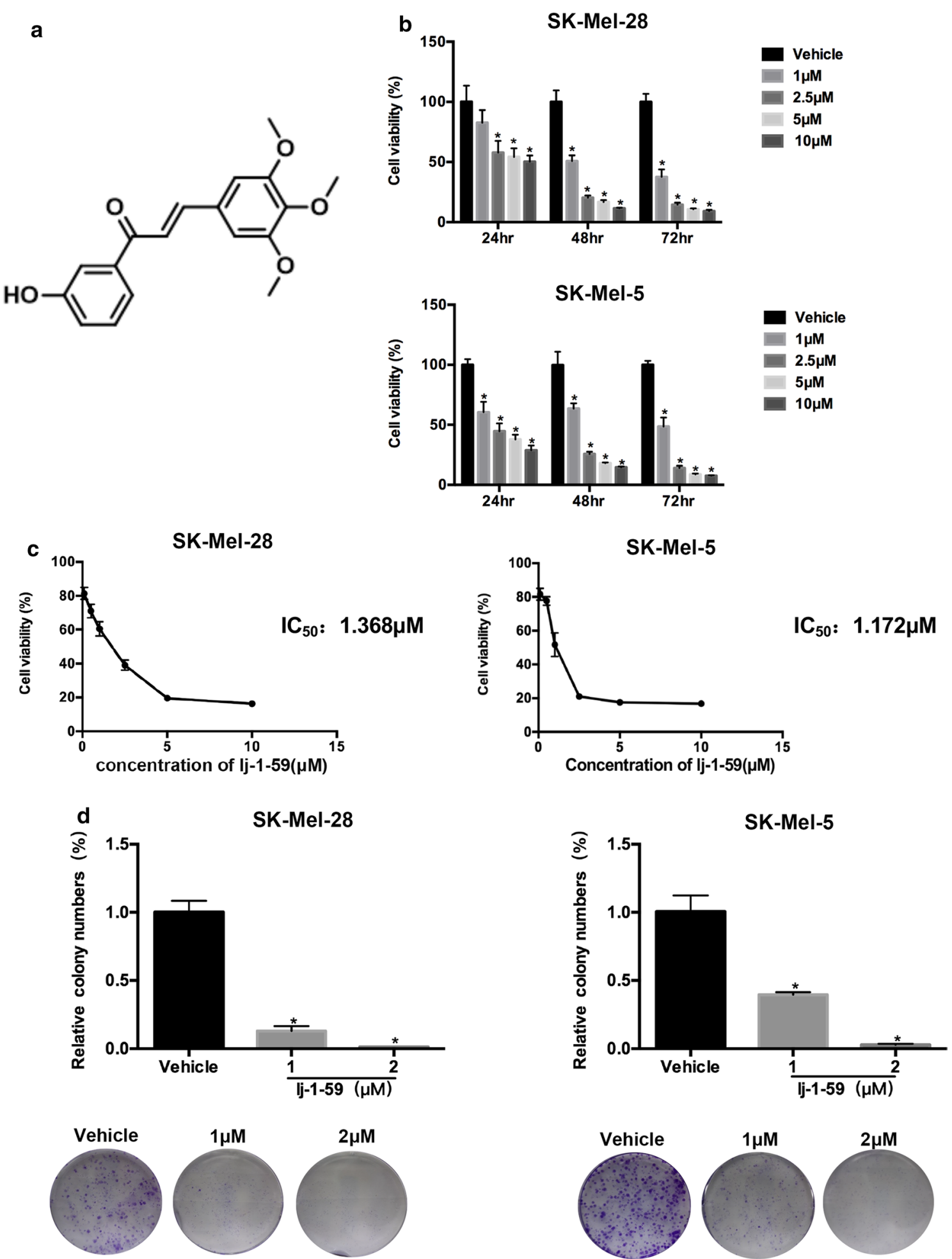

Fig. 1 lj-1-59 inhibits the proliferation of human melanoma cells. a Structure of lj-1-59. b SK-Mel-28 (upper panel) and SK-Mel-5 (lower panel) were prepared in 96-well plates. The cells were treated with increasing dose lj-1-59 for 0-72 h. Cell viability was determined by CCK-8 assay. The results represent the means $(n=6) \pm S D$. Significant differences were evaluated using Student's t-test, and an asterisk $(*)$ indicates a significant difference $(\mathrm{p}<0.05)$. $\mathbf{c}$ The $I_{50}$ values of lj-1-59 in SK-Mel-28 (left panel) and SK-Mel-5 (right panel) cells were automatically calculated for $48 \mathrm{~h}$ by GraphPad Prism software. d SK-Mel-28 (left panel) and SK-Mel-5 (right panel) cells were prepared in 6-well plates. The cells were treated with increasing dose lj-1-59 for $24 \mathrm{~h}$. After 2 weeks, the number of colonies was assessed and quantified as described in "Methods". The data represent the mean $(n=4) \pm S D$, and an asterisk $\left(^{*}\right)$ indicates a significant difference $(p<0.05$, Student's t-test) 


\section{Cytotoxicity assay (CCK-8)}

The cells were seeded onto 96-well plates (2000 cells/ well) and treated with lj-1-59 for 24,48 and $72 \mathrm{~h}$, and the cells were assessed using the CCK- 8 assay (Selleckchem, Houston, USA). We used the OD value of $48 \mathrm{~h}$ after lj-159 treated to calculate the $\mathrm{IC}_{50}$ value. The $\mathrm{IC}_{50}$ values were automatically calculated by using GraphPad Prism software.

\section{Colony formation assay}

The cells were seeded onto 6-well plates (1500 cells/ well) and treated with lj-1-59 or DMSO (Vehicle) for $24 \mathrm{~h}$ under standard culture conditions. Next, the medium was replaced, and the cells were cultured for approximately 14 days in normal medium. The cells were then stained with crystal violet after fixation with $4 \%$ paraformaldehyde.

\section{Cell apoptosis and cell cycle assay}

The cells were treated with lj-1-59 or DMSO (Vehicle) for $48 \mathrm{~h}$ and then stained with Annexin V-FITC/PI (BD Biosciences, New Jersey, USA). Cell apoptosis was measured by flow cytometry and analyzed by using FlowJo software. For the cell cycle assays, the cells after treatment with $1 \mathrm{j}-1-59$, fixed in cold $70 \%$ ethanol and stained with PI for $15 \mathrm{~min}$ at room temperature. Cell cycle was measured by flow cytometry and analyzed by using ModFit software. In another experiment, the cells were treated with $10 \mathrm{mmol} / \mathrm{L} N$-acetylcysteine (NAC) (Beyotime, China) and $5 \mu \mathrm{M} \mathrm{lj-1-59}$ for $48 \mathrm{~h}$, then stained with Annexin V-FITC/PI or PI.

\section{Western blot analysis}

The cells were lysed with RIPA buffer containing protease and phosphatase inhibitors (Selleckchem). For histone extraction, cells were lysed with NETN buffer containing protease and phosphatase inhibitors, and histones were extracted with HCL. The protein concentration was tested with a BCA kit, and appropriate amounts of protein were prepared for SDS-PAGE and then transferred to PVDF membrane (Millipore, MA, USA). The membranes were blocked for $1 \mathrm{~h}$ with $5 \%$ nonfat dry milk and then incubated with rabbit anti-p-ATM mAb (Ser1981; 1:1000; \#5883; CST) and rabbit anti-p-ATR mAb (Ser428; 1:1000; \#2853; CST), mouse anti-P53 (1:500; sc-47698; Santa Cruz) mAb, rabbit anti-ATR mAb (1:1000; \#13934; CST), rabbit anti-ATM mAb (1:1000; \#2873; CST), rabbit anti-PARP mAb (1:1000; \#9532; CST), rabbit anti-Bcl2 mAb (1:1000; Cat. No. 12789-1-AP; Proteintech), rabbit anti-Bax mAb (1:1000; Cat. No. 50599-2-lg; Proteintech), rabbit anti-r-H2AX mAb (Ser139; 1:1000; \#9718; CST), rabbit anti-P21 mAb (1:1000; Cat. No. 10355-1-AP; Proteintech), rabbit anti-H2AX mAb (1:500; D155226-0025;
Sangon Biotech). Additionally, $\alpha$-tubulin (1:1000; \#5335; CST) and GAPDH (1:3000; Cat. No. 60004-1-lg; Proteintech) were used as loading controls. The results were imaged using a gel image analysis system (BioRad, California, USA) according to the manufacturer's instructions.

\section{Quantitative real-time PCR analysis}

Total RNA was extracted from the cell samples using Trizol reagent (Invitrogen, California, USA) according to the manufacturer's instructions. A reverse transcription reaction was performed using the SuperScript III First-Stand Synthesis System (Invitrogen, California, USA). The cDNA was amplified in SYBR Green qPCR mix (TOYOBO, Japan) and loaded onto the 7500 realtime PCR system (Applied Biosystems, MA, USA). GAPDH was used as an internal control. The primer sequences are as follows: hSESN2Fw5'tggctcatcaccaagg aacacatc3'; hSESN2Rv5'aggagagcgagtggcagtgg3'; hACT L8Fw5'gcagcagagtgccttggatgag3'; hACTL8Rv5'tctcgcag gactccacggattc $3^{\prime} ; \mathrm{h} M C M 3 \mathrm{Fw} 5^{\prime}$ tcagacaccgccaggacatctc3 '; hMCM3Rv5'caggtccacagtcttgctcatgc 3'; hMCM4Fw5'c ctcgcctggagtggacctg $3^{\prime} ; \mathrm{h} M C M 4 \mathrm{Rv} 5^{\prime}$ 'gagtgccgtatgtcagtgg tgaac3'; hMCM2Fw5'ggcgaggaggacgaggagatg3'; hMCM 2Rv5'aagttcttgaagcggtggtggatc $3^{\prime} ; \mathrm{h} M C M 7 \mathrm{Fw} 5^{\prime}$ ttggtaact gtgcgtggaatcgtc $3^{\prime} ; \mathrm{h} M C M 7 \mathrm{Rv} 5^{\prime}$ ctggatcggctggtaggtctctg 3'; hCDKN1AFw5'agcgaccttcctcatccacc3'; hCDKN1ARv 5'aagacaactactcccagccccata3'; hBBC3F w5'tctcctctcggtg ctccttcact $3^{\prime} ; \mathrm{h} B B C 3 \mathrm{Rv} 5$ 'acgtttggctcatttgctcttca3'; h $G A D$ $D 45 A \mathrm{Fw}^{\prime}{ }^{\prime}$ ctcaagcagttactaaataca3 ${ }^{\prime}$; and hGADD45ARv5' cttcttcattttcacctctttcca3'.

\section{Measurement of ROS}

The cells were seeded onto $1 \times 10^{6}$ cells in 6-well plates and treated with $5 \mu \mathrm{M} \mathrm{lj-1-59}$ for 0-6 h. In another experiment, the cells were pretreated with $5 \mathrm{mmol} / \mathrm{L} N$-acetylcysteine (NAC) for $1 \mathrm{~h}$, then cultured for $6 \mathrm{~h}$ with $5 \mu \mathrm{M}$ lj-1-59. The medium was changed to serum-free medium, and the cells were incubated with DCFH-DA (Solarbio, China) for $30 \mathrm{~min}$ at $37^{\circ} \mathrm{C}$ in the dark. DCFH-DA was deacetylated by intracellular esterase, which was oxidized by intracellular ROS to the fluorescent DCF. DCF fluorescence was detected using flow cytometer and analyzed by using FlowJo software.

\section{Immunofluorescence analysis}

Cells $\left(3 \times 10^{5} /\right.$ well $)$ were grown on coverslips, treated with $1 \mathrm{j}-1-59$ for $0-48 \mathrm{~h}$, fixed with $4 \%$ paraformaldehyde for $15 \mathrm{~min}$, and permeabilized with $0.5 \%$ Triton X-100 for 15 min. After blocking with 5\% BSA. The cells were incubated with anti- $\gamma \mathrm{H} 2 \mathrm{AX}$ (Ser139; 1:100; \#9718; CST) overnight at $4{ }^{\circ} \mathrm{C}$. The next day, the cells were washed three times with PBS and incubated with secondary antibody 
for $1 \mathrm{~h}$ at room temperature. The cells were counterstained with DAPI and visualized by fluorescence microscopy.

\section{Immunohistochemistry}

Tumors from nude mice were fixed and embedded in paraffin. The sections were baked at $65{ }^{\circ} \mathrm{C}$ for $2 \mathrm{~h}$ and treated with hydrogen peroxide after dehydrating in a series of graded alcohols. Antigen retrieval was performed by heat treatment in a pressure cooker in citrate buffer $(\mathrm{pH}=6.0)$. The slides were blocked in goat serum for $1 \mathrm{~h}$. Subsequently, the slides were incubated with Ki67 (1:400; ab16667; Abcam) at $4{ }^{\circ} \mathrm{C}$ overnight. The slides were incubated with a specific HRP-conjugated secondary antibody and stained with DAB. After PBS rinsing, the samples were counterstained in hematoxylin, dehydrated and mounted.

\section{Animal studies}

Female BALB/c nude mice (5 weeks old) were purchased from the Central South University. Fifteen mice (18 g) were divided randomly into 3 groups, including the vehicle

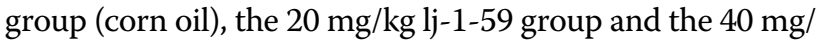
kg lj-1-59 group. Sk-Mel-5 cells $\left(2 \times 10^{6}\right)$ were subcutaneously injected into the flanks of mice. When the tumors reached $50 \mathrm{~mm}^{3}$ or larger, each group of mice was injected through intraperitoneal injection with the corresponding drugs once a day for $2-3$ weeks (approximately 16 times). The tumor size was measured using a caliper three times a week, and the tumor volume was calculated with the formula $V=1 / 2$ (length $\times$ width $^{2}$ ). When the tumors reached $1000 \mathrm{~mm}^{3}$, the mice were sacrificed, and the tumors were collected. The tumors were photographed. Furthermore, the tumor sections were immunostained.

\section{Statistical analysis methods}

The significant differences between different groups was determined with ANOVA and Student's t-test. A $p$-value $<0.05$ was considered statistically significant. Statistical analysis was performed by GraphPad Prism.

\section{Results}

lj-1-59 blocks melanoma cell growth in vitro and in vivo

lj-1-59 is a novel chalcone derivative (Fig. 1a), and we determined the effect of $1 j-1-59$ on melanoma cell growth. As shown in Fig. 1b and Additional file 1: Fig. S2a, the cell viability was significantly reduced after 1j-1-59 treatment in various melanoma cells in a doseand time-dependent manner. The $\mathrm{IC}_{50}$ values in SKMel-5, SK-Mel-28 and A375 were $1.172 \mu \mathrm{M}, 1.368 \mu \mathrm{M}$ and $2.002 \mu \mathrm{M}$, respectively, after $48 \mathrm{~h} \mathrm{lj-1-59}$ treatment (Fig. 1c and Additional file 1: Fig. S2a). Moreover, lj-1-59 treatment remarkably abrogated melanoma cell colony formation and growth on plates (Fig. 1d and Additional file 1: Fig. S2b). In addition, as shown in Additional file 1: Fig. S1, The $\mathrm{IC}_{50}$ values in PIG1 (human melanocyte cell line), JB6 (normal mouse skin epidermal cell line) and BJ (normal human skin fibroblast cell line) were $4.2 \mu \mathrm{M}, 5.3 \mu \mathrm{M}$ and $5.9 \mu \mathrm{M}$, respectively. $\mathrm{IC}_{50}$ values in $\mathrm{H} 9 \mathrm{C} 2$ (normal human heart myoblast cells) was greater than $10 \mu \mathrm{M}$. These results suggested that the cytotoxicity of lj-1-59 was selective to melanoma cells. Taken together, these results confirmed that lj-1-59 inhibited the growth properties of human melanoma cells, including SK-Mel-5, SK-Mel-28 and A375. To study the effects of lj-1-59 on melanoma cell growth in vivo, we generated a melanoma cell xenograft mouse model. Consistent with previous results in vitro, 1j-1-59 treatment reduced tumor burden at both low and high dosages (Fig. 2a, b) but did not affect body weight, indicating that this compound has low toxicity. Moreover, Ki67 staining was decreased in xenograft tissue after lj-1-59 treatment (Fig. 2c, d), suggesting that lj-1-59 significantly attenuates melanoma cell growth in vivo.

\section{lj-1-59 arrests the cell cycle at G2/M phase and induces apoptosis in melanoma cells}

Previous results demonstrated that $1 \mathrm{j}-1-59$ suppresses melanoma cell growth in vitro and in vivo. Here, we showed that this compound induced cell cycle arrest at the G2/M phase and promoted apoptosis. As shown in Fig. 3a and Additional file 1: Fig. S2c, the cell cycle was arrested in the G2/M phase after $1 \mathrm{j}-1-59$ treatment in melanoma cells. In addition, we found that $5 \mu \mathrm{M}$ of $1 j-1-59$ treatment induced $21.7 \%, 27.5 \%$ and $38.1 \%$ apoptosis in SK-Mel-5, SK-Mel-28 and A375 (Fig. 3b and Additional file 1: Fig. S2d) cells, respectively. Moreover, this compound induced PARP cleavage and increased BAX expression, whereas BCL2 expression was downregulated after $1 j-1-59$ treatment in different melanoma cell lines (Fig. 3c and Additional file 1: Fig. S2e).

\section{lj-1-59 treatment affects the cell cycle and DNA damage according to RNA-Seq}

To identify the possible molecular mechanism of lj-1-59 for antitumor activity, we analyzed transcriptional alterations in melanoma cells after lj-1-59 treatment in various melanoma cell lines. The RNA-seq results showed that most genes were up-regulated, whereas other genes were down-regulated after $48 \mathrm{~h}$ treatment (Fig. 4a and Additional file 1: Fig. S3a). The top 20 enriched pathways included p53, TNF, FoxO, MAPK, apoptosis and cell cycle pathways (Fig. 4b and Additional file 1: Fig. S3b) according to a KEGG database analysis in differentially expressed genes. Moreover, the GSEA analysis 


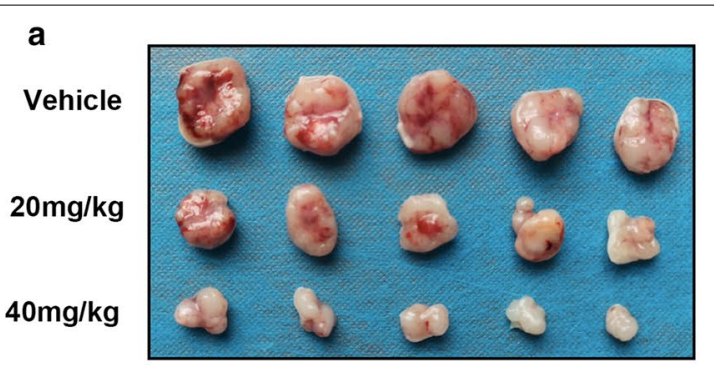

b

Vehicle

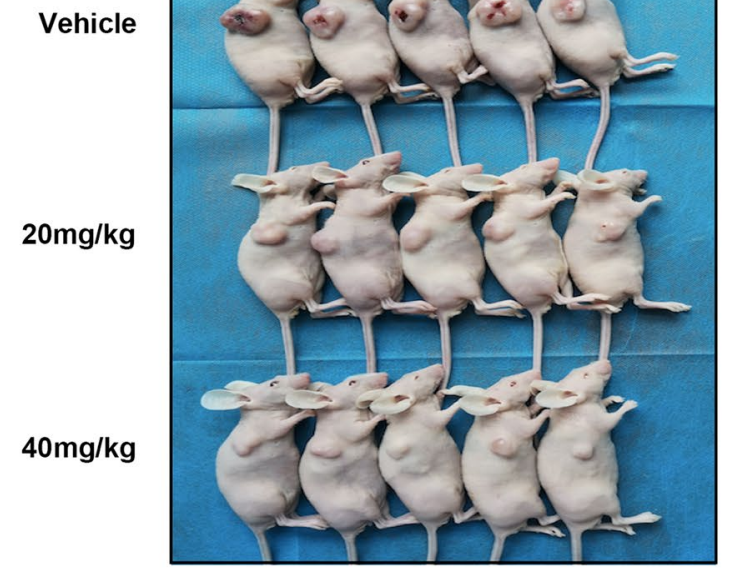

Ki67

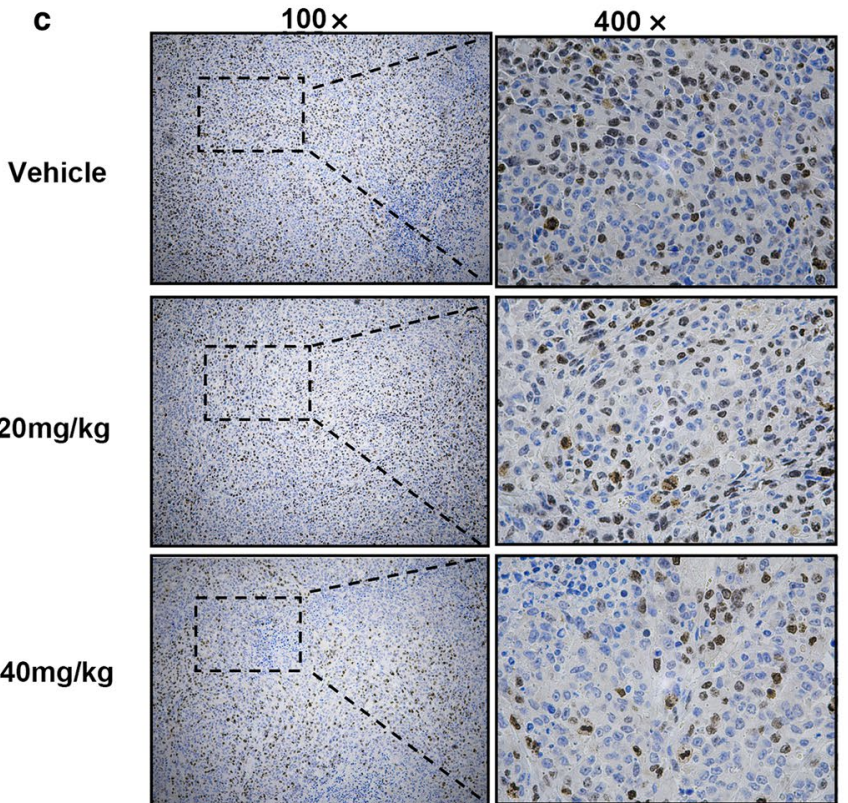

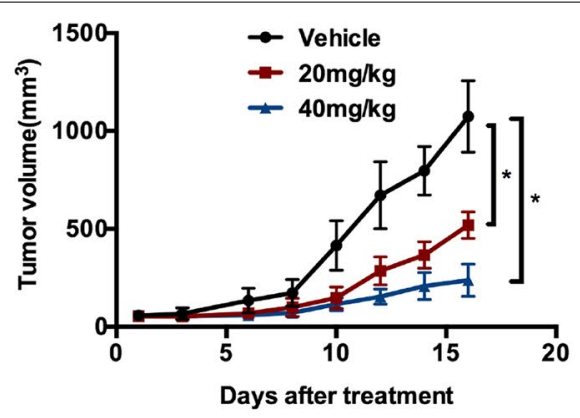

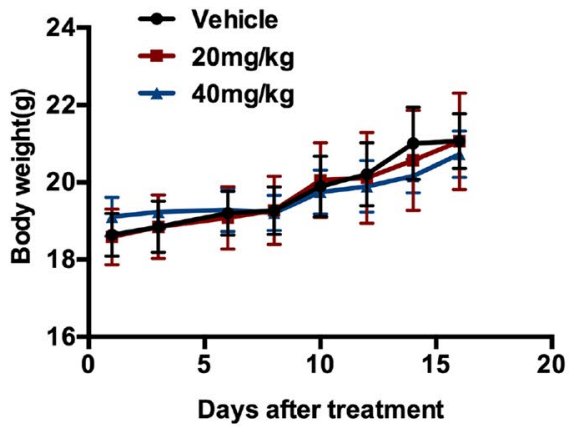

d

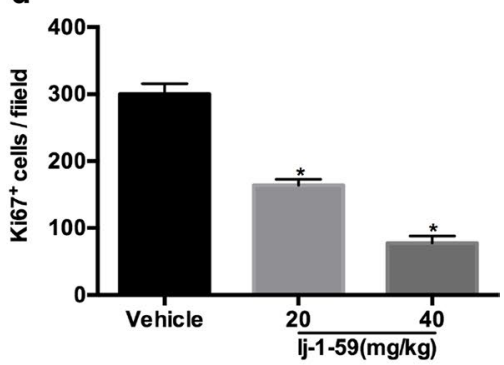

Fig. 2 lj-1-59 suppresses xenograft tumor growth in vivo. a The tumor volume of nude mice. $\mathbf{b}$ The body weight of nude mice. The results in $\mathbf{a}$ and $\mathbf{b}$ are shown as the mean $(n=5) \pm S D$, and asterisk $\left(^{*}\right)$ indicates a significant difference $(p<0.05$ one way ANOVA). c Representative images of IHC staining of Ki67 in tumor tissues. $\mathbf{d}$ Quantification of the Ki67 staining. Five images fields were analyzed per tumor slice. The results represent the means $(n=5) \pm S D$, and asterisk $\left(^{*}\right)$ indicates a significant difference $(p<0.05$, Student's t-test) 

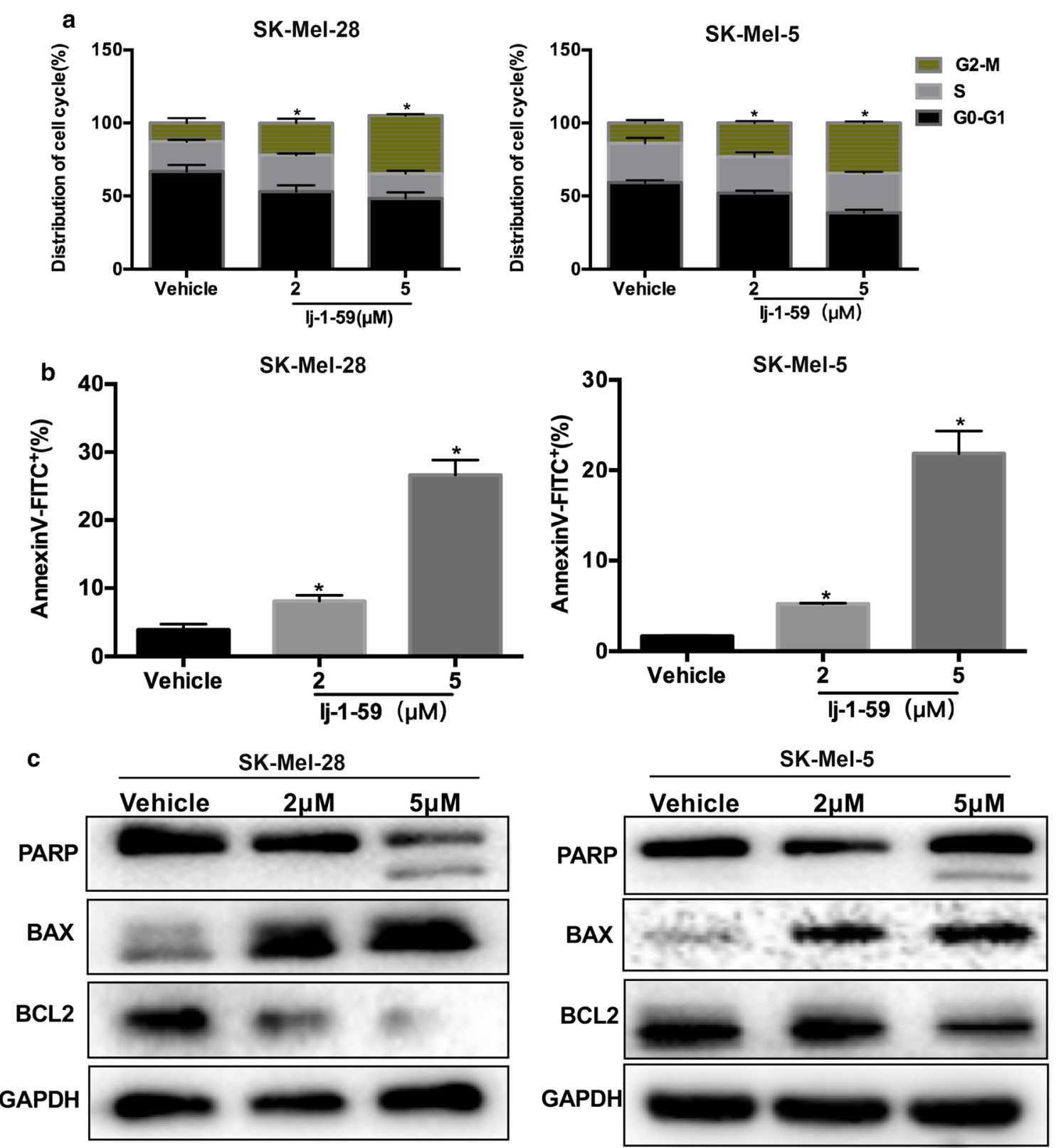

Fig. 3 lj-1-59 arrest the cell cycle at G2/M phase and induce apoptosis in melanoma cells. a Cell cycle analysis of SK-Mel-28 (left panel) and SK-Mel-5 (right panel) cells with increasing dose lj-1-59 for the $48 \mathrm{~h}$. The cell cycle distribution was detected by flow cytometry as described in "Methods". The results represent the means $(n=4) \pm S D$, and asterisk $\left(^{*}\right)$ indicates a significant difference $(p<0.05$, Chi-square test). $\mathbf{b}$ Apoptosis analysis of SK-Mel-28 (left panel) and SK-Mel-5 (right panel) cells with increasing dose lj-1-59 for $48 \mathrm{~h}$. The results represent the means $(n=4) \pm S D$, and asterisk $\left(^{*}\right)$ indicates a significant difference $(p<0.05$, Student's t-test). $\mathbf{c}$ Western Blot analysis of apoptosis-associated proteins in SK-Mel-28 (left panel) and SK-Mel-5 (right panel) cells with lj-1-59 treatment for $48 \mathrm{~h}$

revealed that the effect of $1 \mathrm{j}-1-59$ was related to the cell cycle and DNA damage (Fig. 4c and Additional file 1: Fig. S3c), which is consistent with previous results. Based on the above analysis, we hypothesized that cell cycle and DNA damage were pivotal pathways regulated by this compound. Next, we verified key differentially expressed genes, including P21 (CDKN1A), PUMA (BBC3), GADD45A, PKMYT1, SESN2, MCM2, MCM3, MCM4 and $M C M 7$ (Fig. 4d, Additional file 1: Figs. S3d, S4e), which play crucial roles in the cell cycle or DNA damage. 
a

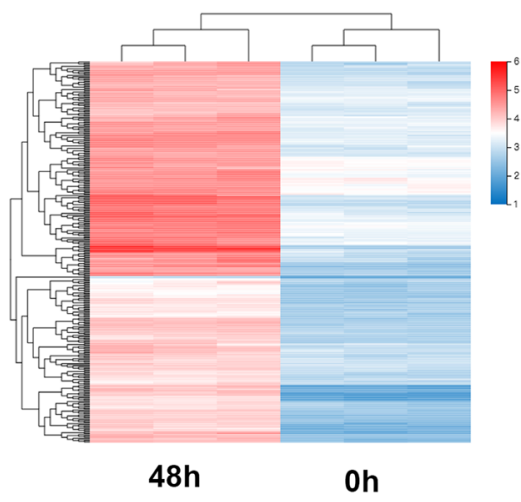

b Enriched KEGG Pathway for SK-Mel-28

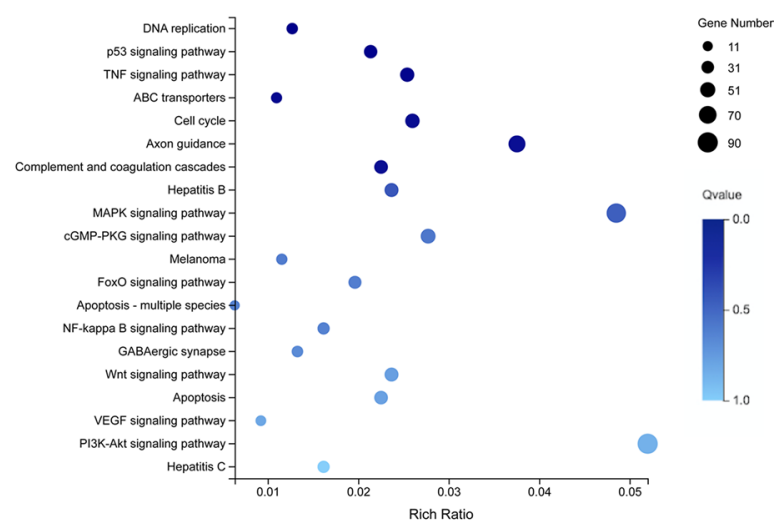

C GSEA enrichment plots for SK-Mel-28

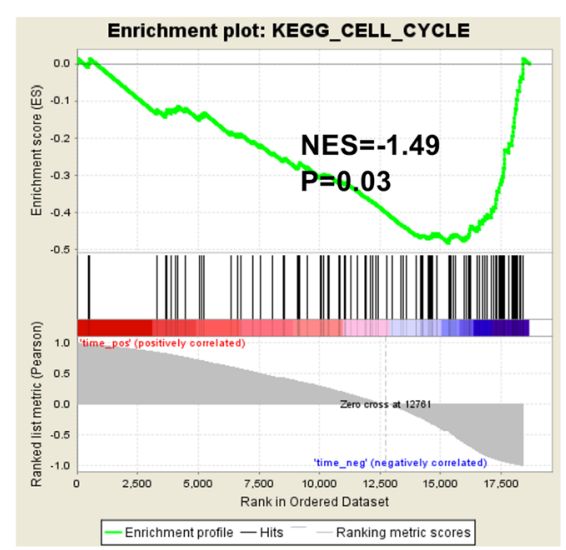

d
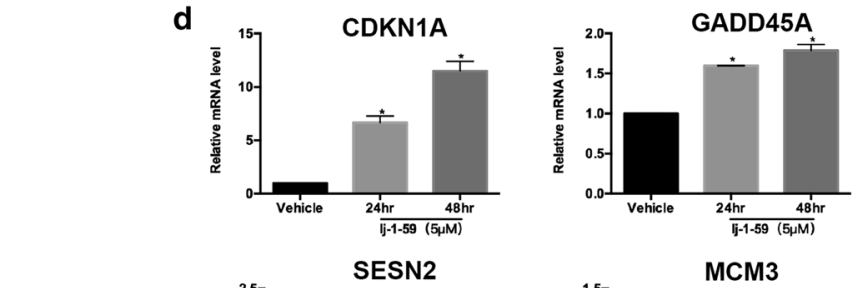

MCM3
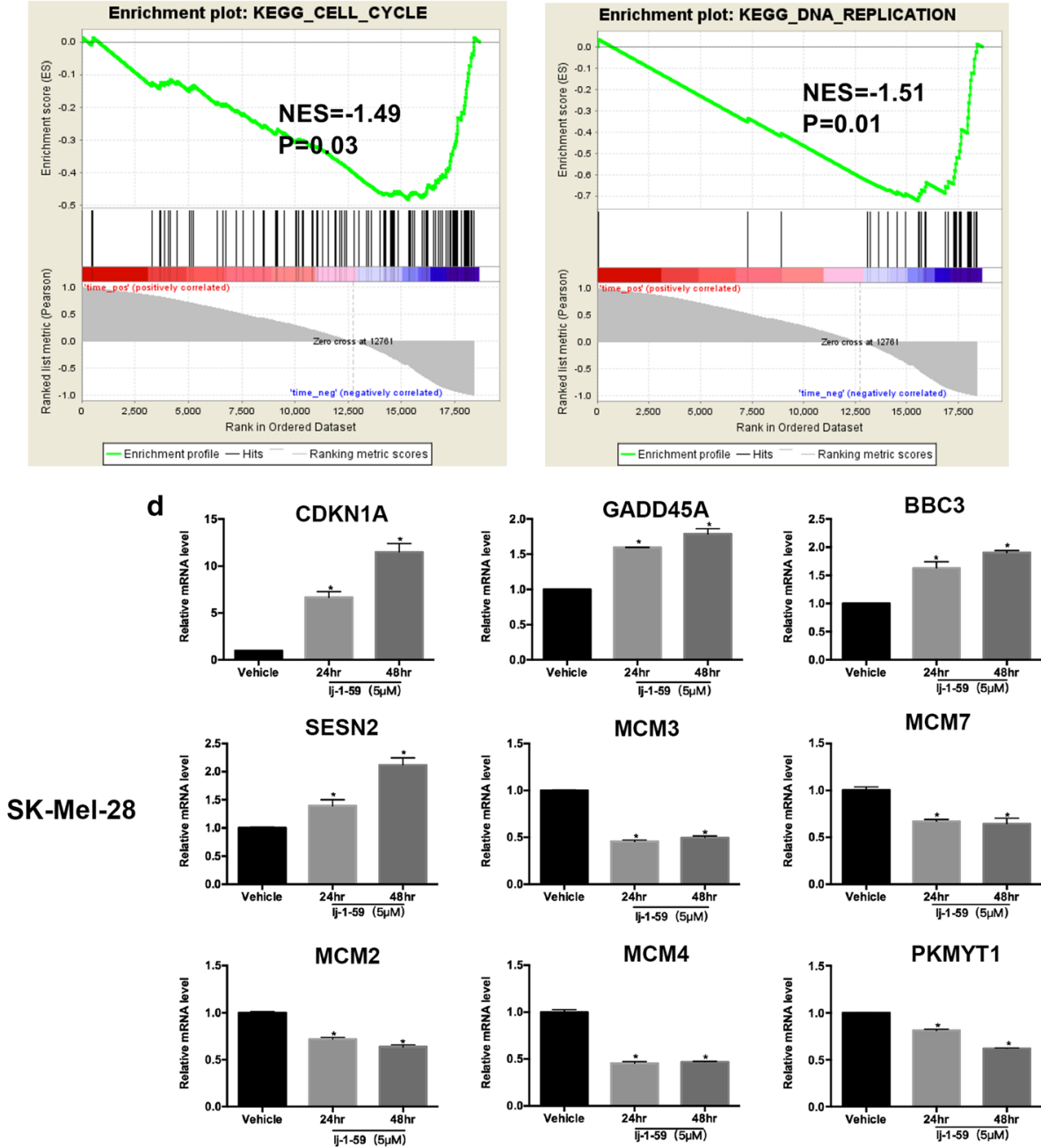

Fig. 4 RNA-seq analyses of the effect of lj-1-59 on the gene expression profile. a The heatmap of SK-Mel-28 after lj-1-59 treatment. b Top 20 enriched KEGG pathways after lj-1-59 treated. c GSEA enrichment plots after lj-1-59 treated, and Normalized enrichment score (NES) and Normalized p-value (P) are shown in each plot. d SK-Mel-28 cells were treated with $5 \mu \mathrm{M} \mathrm{lj-1-59} \mathrm{for} 48 \mathrm{~h}$. Then extract total RNA to Q-RT-PCR analysis as described in "Methods". The results are expressed as the mean $(n=6) \pm$ SD. Significant differences were evaluated using Student's t-test, and an asterisk $\left(^{*}\right)$ indicates a significant difference $(p<0.05)$ 


\section{lj-1-59 treatment induces DNA toxicity by increasing ROS products}

ROS are produced by aerobic metabolism, which initiates various biological functions, such as DNA toxicity, cellular death and chronic inflammation [30]. The increase in ROS products has been involved in tumorigenesis and anticancer effects, depending on the level of these products. At a lower level, ROS promote carcinogenesis through the regulation of proliferation, angiogenesis and metastasis, while a high level of ROS induces DNA toxicity, resulting in cellular apoptosis and cell death, which leads to antitumor effects [31]. Unexpectedly, we found that lj-1-59 treatment significantly induced ROS products in melanoma cell lines (Fig. 5a and Additional file 1: Fig. S4a). Additionally, lj-1-59 treatment remarkably activates the ATM/ATR signaling pathway, including p-ATM, p-ATR, $\gamma$ H2AX, P53, p-P53 and P21 (Fig. 5b and Additional file 1: Fig. S4d). ATM or ATR plays critical roles in DNA damage responses and activates downstream molecules, including the p53 pathway, which causes cell cycle arrest at the G2/M phase and apoptosis [32, 33]. $\gamma \mathrm{H} 2 \mathrm{AX}$ is a biomarker of DNA damage, and lj-1-59 treatment also increases the accumulation of $\gamma \mathrm{H} 2 \mathrm{AX}$ in the nucleus (Fig. 5c, d and Additional file 1: Fig. S4b, c). To investigate the association of ROS generation with lj-1-59-induced cell death, we exposed Sk-Mel-28 cells to lj-1-59 in the absence or presence of NAC ( $N$-acetylcysyeine, ROS scavenger). Then we detected anti-apoptotic and anti-arrest cell cycle effect of NAC in lj-1-59-induced cell death by flow cytometry. NAC can significantly reduced lj-1-59-induced cell apoptosis compared with lj-1-59 treatment (Additional file 1: Fig. S5b). In addition, the G2/M phase arrest was reversed partly to control levels in SK-Mel-28 co-treated with NAC (10 mM) and lj-159 (Additional file 1: Fig. S5a). These data indicate that ROS play an essential role in the apoptosis and cell cycle induced by lj-1-59 in melanoma cells. Next, We verified the role of NAC in inhibiting ROS generation using flow cytometry. The results show that the levels of ROS can be impeded by NAC (Additional file 1: Fig. S5c). Taken together, these data suggested that lj-1-59 treatment raises ROS products and induces DNA damage and apoptosis in melanoma cells.

\section{lj-1-59 attenuates BRAFi-resistant melanoma cell growth}

The dysregulation of RAS/MAPK and PI3K/AKT with BRAF mutations in $60 \%$ of patients showed that these pathways are key drivers of melanoma development and progression [34, 35]. Although the administration of a BRAF inhibitor (such as vemurafenib) improves patient survival, approximately $70 \%$ of patients acquire drug resistance within 6 months [36, 37]; therefore, overcoming drug resistance is a challenge for melanomatargeting therapeutic treatments. The BRAF-resistant cells (RA) from parental A375 cells were generated as described previously [9, 38] (Fig. 6a). Surprisingly, our finding showed that lj-1-59 treatment dramatically reduced cell viability in a dose- and time-dependent manner in $\mathrm{RA}$ cells, and the $\mathrm{IC}_{50}$ value for $1 \mathrm{j}-1-59$ was $2.69 \mu \mathrm{M}$ (Fig. 6b), and this compound also inhibited melanoma cell growth on plates (Fig. 6c). Similar to its effects on regular melanoma cells, lj-1-59 treatment causes cell cycle arrest at the G2/M phase (Fig. 6d) and apoptosis (Fig. 6e), including upregulating the expression of cleaved PARP and BAX and decreasing BCL2 expression (Fig. 6f). Consistent with the previous results, NAC can significantly reduced lj-1-59-induced cell apoptosis (Additional file 1: Fig. S5b) and partly reversed the G2/M arrest (Additional file 1: Fig. S5a). lj-1-59 treatment significantly increased ROS products (Fig. 7a), which can be impeded by NAC (Additional file 1: Fig. S5c), leading to DNA toxicity, which increased p-P53, P21, p-ATR, and p-ATM expression (Fig. 7b) and $\gamma \mathrm{H} 2 \mathrm{AX}$ foci formation (Fig. 7c). Furthermore, we found that $1 \mathrm{j}-1-59$ treatment significantly influences P21 (CDKN1A), PUMA (BBC3), GADD45A, PKMYT1, SESN2, MCM2, MCM3, $M C M 4$ and $M C M 7$ expression at the transcriptional level (Fig. 7d), which is consistent with the results in non-BRAFi-resistant melanoma cells, indicating that this compound has antitumor activity for melanoma treatment, regardless of BRAFi resistance.

\section{Discussion}

Natural products and their synthetic analogues are characterized by low cytotoxicity and antitumor activity, which have been a concern for the development of antitumor drugs [39]. Among these natural products, chalcone exhibits diverse biological activities, including antitumor effects [23]; for example, chalcone directly inhibits the activity of IKB kinases (IKKs), which subsequently reduces downstream NF- $\mathrm{B}$ activation, resulting in enhanced apoptosis induced by TNF or chemotherapeutic drugs [40]. Chalcone also inhibits VEGF-induced endothelial cell growth and angiogenesis through the PI3K/AKT signaling pathway in vivo [41].

In this study, we investigated the effects of $1 j-1-59$, a chalcone derivative, on melanoma treatment. Our results demonstrated that lj-1-59 significantly inhibited the growth of melanoma cells, regardless of BRAFi resistance both in vitro (Figs. 1 and 6) and in vivo (Fig. 2). The $\mathrm{IC}_{50}$ values for 1j-1-59 in SK-Mel-5, SK-Mel-28, and A375 were $1.172 \mu \mathrm{M}, 1.368 \mu \mathrm{M}$ and $2.002 \mu \mathrm{M}$, respectively (Fig. 1c, Additional file 1: Fig. S2a). Moreover, we also found that 1 -1-59 treatment induced cell cycle arrest and apoptosis (Fig. 3a-c, Additional file 1: Fig. 

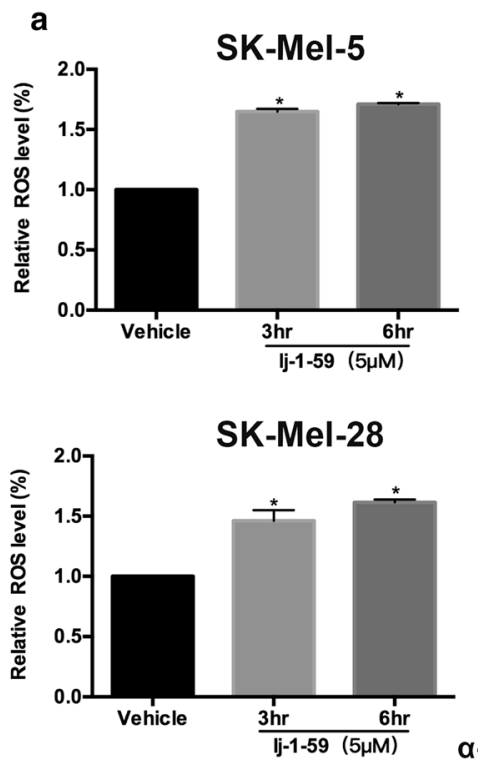

b SK-Mel-5

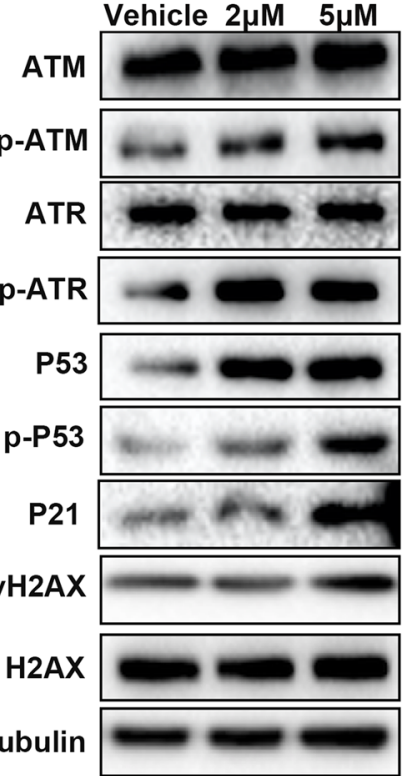

SK-Mel-28

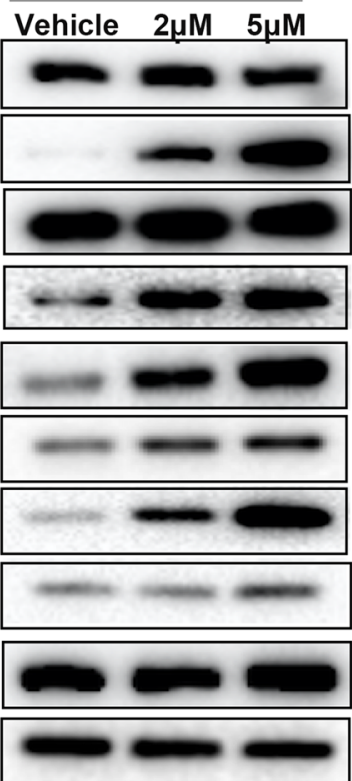

c SK-Mel-28

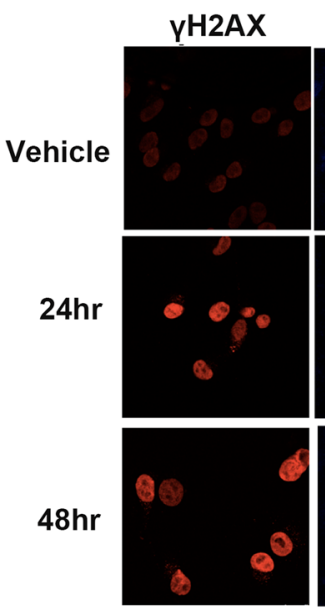
DAPI

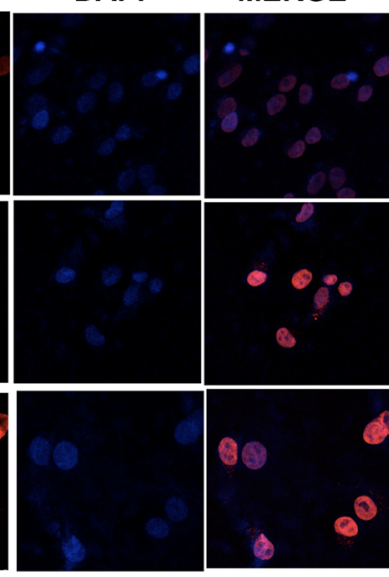

d

SK-Mel-28

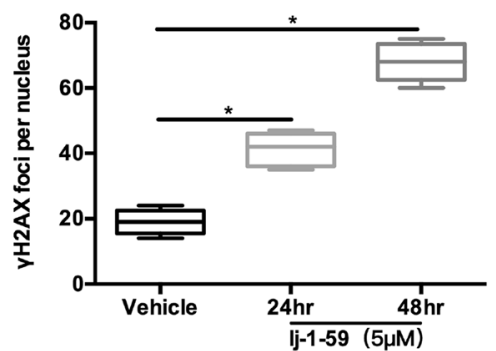

SK-Mel-5

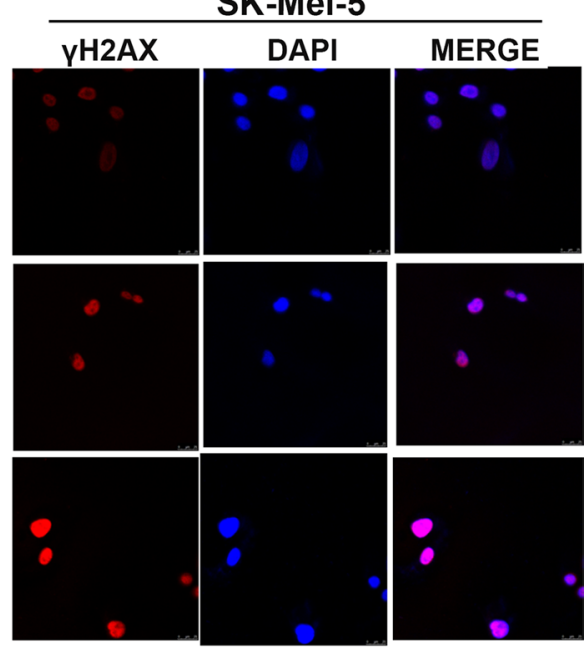

SK-Mel-5

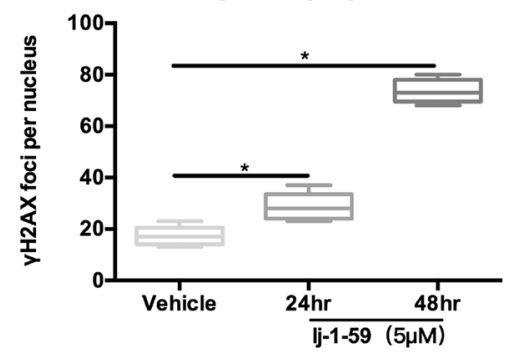

Fig. 5 lj-1-59 treatment induces DNA damage by increasing ROS. a The level of ROS of SK-Mel-5 (upper panel) and SK-Mel-28 (lower panel) cells

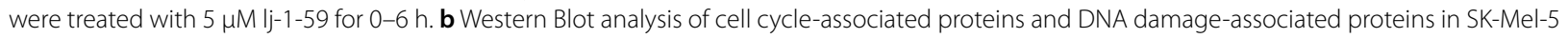
(left panel) and SK-Mel-28 (right panel) cells with increasing does lj-1-59 treatment for 48 h. c, d YH2AX of SK-Mel-28 (left panel) and SK-Mel-5 (right panel) cells were stained by immunofluorescence after $5 \mu \mathrm{M} \mathrm{lj-1-59}$ treated and calculated. The results in $\mathbf{d}$ was represent as the mean $(n=6) \pm S D$, and asterisk $\left(^{*}\right)$ indicates a significant difference using Student's t-test $(p<0.05)$ 


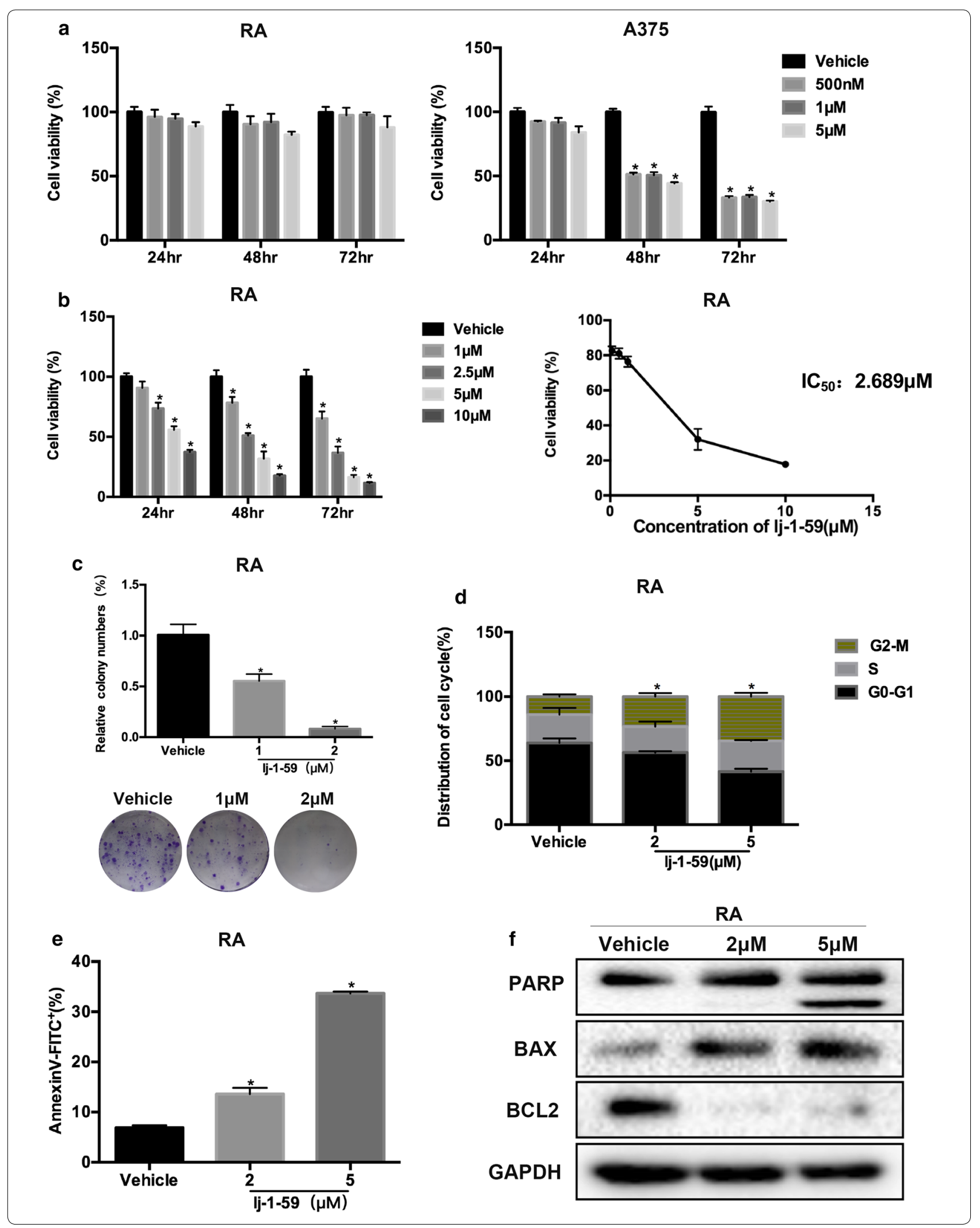




\begin{abstract}
(See figure on previous page.)
Fig. 6 Effect of Ij-1-59 on BRAFi-resistant melanoma cells. a BRAFi-resistant melanoma cells (RA) were generated as described in "Methods". RA (left panel) and parental A375 (right panel) cells were prepared in 96-well plates. The cells were treated with PLX4032. Cell viability was determined by CCK-8 assay. The results represent the means $(n=6) \pm S D$, and asterisk $\left(^{*}\right)$ indicates a significant difference $(p<0.05$, Student's t-test). b RA cells were treated with increasing dose lj-1-59 for 0-72 h (left panel). Cell viability was determined by CCK-8 assay. The results represent the means $(n=6) \pm S D$, and asterisk $\left(^{*}\right)$ indicates a significant difference ( $p<0.05$, Student's t-test). The $I C_{50}$ values of $\mid j-1-59$ in RA cells were automatically calculated by GraphPad Prism software (right panel). c RA cells were prepared in 6-well plates. The cells were treated with increasing dose lj-1-59 for $24 \mathrm{~h}$. After 2 weeks, the number of colonies was assessed and quantified as described in "Methods". The results represent the means $(n=5) \pm S D$, and asterisk $\left(^{*}\right)$ indicates a significant difference ( $p<0.05$, Student's t-test). $\mathbf{d}$ Cell cycle analysis of RA cells with increasing dose lj-1-59 for the $48 \mathrm{~h}$. The cell cycle distribution was detected by flow cytometry as described in "Methods". The results are expressed as the means $(n=4) \pm S D$, and asterisk $(*)$ indicates a significant difference $(p<0.05$, Chi-square). e RA cells were treated with increasing dose lj-1-59 for the $48 \mathrm{~h}$. Apoptosis was detected by flow cytometry as described in "Methods". The results are expressed as the means $(n=4) \pm S D$, and asterisk $\left(^{*}\right)$ indicates a significant difference $(p<0.05$, Student's t-test). $\mathbf{f}$ Western Blot analysis of apoptosis-associated proteins in RA cells with lj-1-59 treatment for $48 \mathrm{~h}$. GAPDH was used as a loading control
\end{abstract}

S2c-e). Although we found that the $\mathrm{IC}_{50}$ values of $\mathrm{Ij}-1-$ 59 to immortalized non-tumorigenic cells is higher than melanoma cells, it is still difficult to calculate therapeutic index of the drug, which is a shortage of this study. In future study, drug toxicology, metabolism and other related experiments will be performed to test the safety of this compound in vivo, which provide more evidences for final clinical administration.

Next, we performed RNA-seq to investigate the effect of $1 j-1-59$ on the signaling pathways. The major pathways, such as DNA replication, P53, cell cycle, and apoptosis, were affected after lj-1-59 treatment (Fig. 4a-c, Additional file 1: Fig. S3a-c). We additionally confirmed the expression with mRNA levels of key genes after treatment with lj-1-59 in melanoma cells, which indicated that P21, BBC3, SESN2 and GADD45A expression were significantly upregulated, while $M C M 2, M C M 3, M C M 4$, MCM7 and PKMYT1 were significantly downregulated (Fig. 4d, Additional file 1: Figs. S3d, S4e). P53 is a tumor suppressor gene, and since its discovery, the inhibitory effect of this molecule on tumor growth has been extensively studied. P53 responds to various types of stress, such as DNA damage and hypoxia, and as a result, this protein plays an important role in supporting cell survival and promoting cell death [42]. P53 protects cells from mild stress damage by eliminating ROS, but ROS accumulation in turn can induce p53-mediated apoptosis in cancer cells [43-45].
P21 plays a key role in cell cycle regulation, which is a well-known targeting gene regulated by $\mathrm{p} 53$ in response to various stresses, including DNA damage-induced cell cycle arrest, particularly in the $G 2 / \mathrm{M}$ phase [46-49]. SESN2 is a stress-inducing protein that is also considered a downstream molecule of p53 [50]. GADD45A is a sensor molecule for ROS-induced DNA damage by directly inducing cell cycle arrest and apoptosis [51-54]. MCM2-7 is required for the initiation and elongation steps of DNA replication, which have essential functions in DNA replication [55]. Accumulating evidence has shown that MCM2-7 is significantly overexpressed in various tumors, such as cervical cancer and breast cancer. Moreover, MCM4 and MCM6 expression are clinically relevant to tumor stage [56]. In addition, a novel finding demonstrated that MCM proteins not only regulate S-phase checkpoints but also directly interact with key checkpoint components to regulate DNA repair procedures after DNA damage $[57,58]$.

The maintenance of genomic stability after DNA toxicity mainly depends on the DNA damage repair system and the cell cycle checkpoint. DNA damage induces the arrest of the cell cycle at the G2/M phase to delay cell cycle progression, ensuring sufficient time to repair damaged DNA $[59,60]$. During DNA damage, ATM or ATR activates a variety of downstream pathways, including p53, which leads to cycle arrest or apoptosis [61-63]. In our study, p-ATR, p-ATM, $\gamma$-H2AX at Ser139, p-p53 and

\footnotetext{
(See figure on next page.)

Fig. 7 lj-1-59 induces DNA damage by increasing ROS in RA cells. a RA cells were treated with $5 \mu \mathrm{M}$ lj-1-59 for 0-6 h, the level of ROS was measured by flow cytometry. The results are expressed as the means $(n=4) \pm S D$, and asterisk $\left(^{*}\right)$ indicates a significant difference ( $p<0.05$, Student's t-test). b Western Blot analysis of cell cycle-associated proteins and DNA damage-associated proteins in RA cells with increasing does lj-1-59 treatment for 48 h. a-tubulin was used as a loading control. c RA cells were treated with $5 \mu \mathrm{M}$ for $0-48 \mathrm{~h}$, and $\mathrm{\gamma H} 2 \mathrm{AX}$ was stained by immunofluorescence (left panel) and calculated (right panel). The results are expressed as the mean $(n=5) \pm S D$, and asterisk $\left(^{*}\right)$ indicates a significant difference $(p<0.05$, Student's t-test). d RA cells were treated with $5 \mu \mathrm{M}$ lj-1-59 for $48 \mathrm{~h}$. Then extract total RNA to Q-RT-PCR analysis as described in "Methods". The results are expressed as the mean $(n=5) \pm S D$. Significant differences were evaluated using Student's t-test, and an asterisk $\left(^{*}\right)$ indicates a significant difference $(p<0.05)$
} 


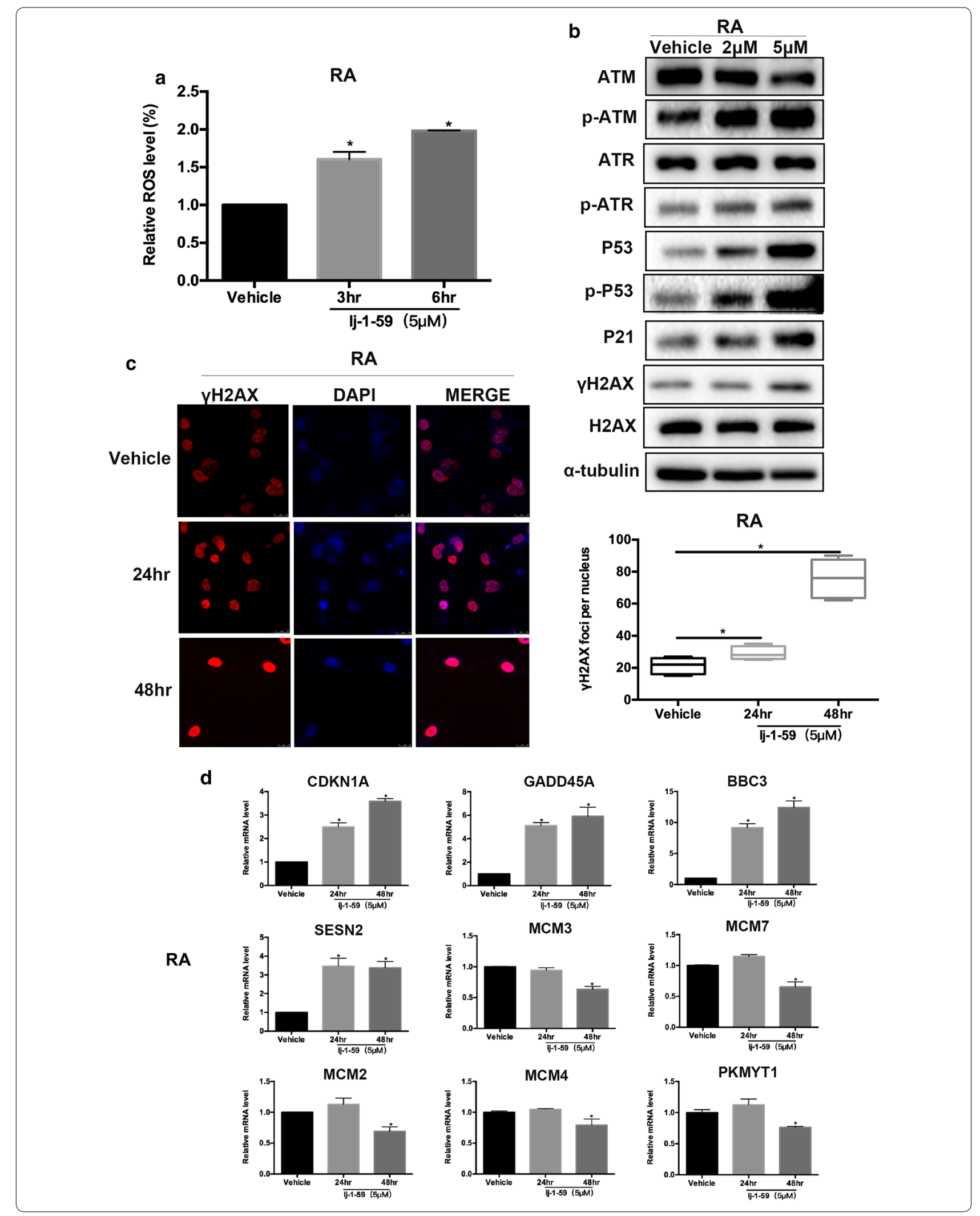




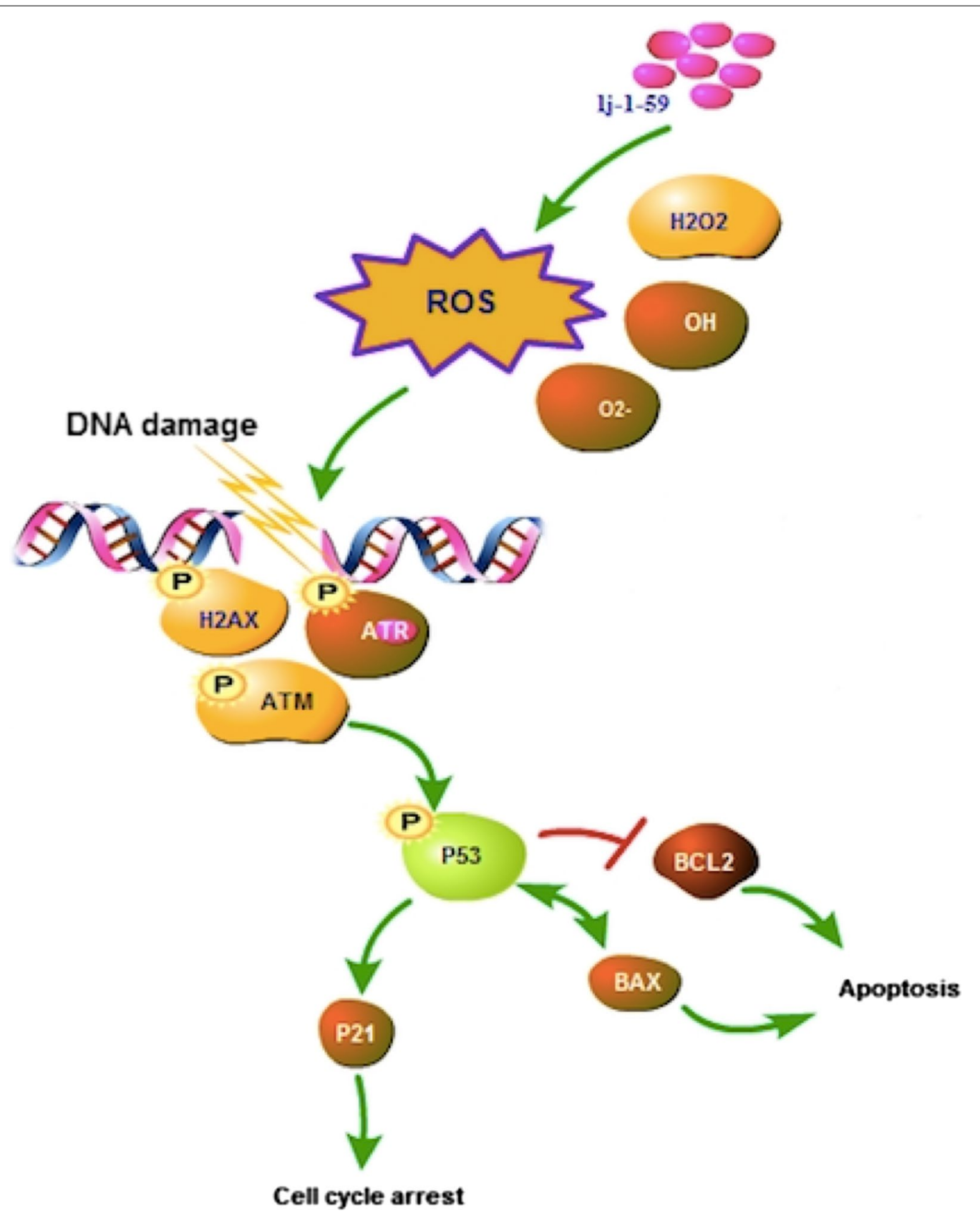

Fig. 8 Schematic diagram of the mechanism of lj-1-59. lj-1-59 induces DNA damage by increasing intracellular ROS levels. ATM and ATR are activated after DNA damage, then regulating downstream target protein P53, leading to cell cycle arrest and apoptosis

p53 were upregulated after lj-1-59 treatment (Fig. 5b, Additional file 1: Fig. S4d), indicating that lj-1-59 has DNA toxicity. Interestingly, lj-1-59 treatment significantly increased ROS products (Fig. 5a, Additional file 1: Fig. S4a), and NAC can not only impeded the generation of ROS (Additional file 1: Fig. S5c), but also significantly induced lj-1-59-induced cell apoptosis, partly reversed the G2/M arrest (Additional file 1: Fig. S5a, b). Reactive oxygen species (ROS) are a class of oxygenates that are directly or indirectly converted from molecular oxygen, which has a more active chemical property [64]. It is reported that the generation of ROS in cancer may be due to the reduction of free radical scavenging enzymes or Warburg effect [65]. Although physiologically active oxygen (ROS) levels are necessary to maintain many cellular functions, excessive ROS production could disrupt 
oxidative balance, leading to cell damage and cell death [66]. Evidence has shown that malignant cells are more susceptible to oxidative stress than normal cells [67]; therefore, a high level of ROS causes DNA damage, which eventually leads to tumor cell necrosis and apoptosis.

\section{Conclusions}

In this study, we found that lj-1-59 treatment inhibits melanoma cell growth in vitro and in vivo through induced apoptosis and DNA damage by increasing ROS levels (Fig. 8), regardless of BRAFi resistance, suggesting that this compound is a potential therapeutic drug for melanoma treatment.

\section{Supplementary information}

Supplementary information accompanies this paper at https://doi. org/10.1186/s12935-020-1114-5.

Additional file 1. Additional figures.

\section{Abbreviations}

CCK-8: Counting Kit-8; BRAFi: BRAF inhibitor; ROS: reactive oxygen species; NGS: next generation sequencing; PI: propidium iodide; NAC: N-acetylcysteine.

\section{Acknowledgements}

Not applicable.

\section{Authors' contributions}

Participated in research design: CP, JZ, XC. Conducted experiments: KL. Contributed new reagents or analytic tools: JL, JS. Performed data analysis: LW, JT, JZ. Wrote or contributed to the writing of the manuscript: KL, SZ. All authors read and approved the final manuscript.

\section{Funding}

This work was financially supported by Major Projects of International Cooperation and Exchanges NSFC Grant No. 81620108024 and Grant No. 81572679,81773341 , 81772917 from the National Natural Science Foundation; The Strategy-Oriented Special Project of Central South University in China (ZLXD2017003).

\section{Availability of data and materials}

The RNA-seq data was uploaded on NCBI (PRJNA545860).

\section{Ethics approval and consent to participate}

The study was approved by the Ethics Committee of the Xiangya Hospital (Central South University).

\section{Consent for publication}

Not applicable.

\section{Competing interests}

The authors declare that they have no competing interests.

\section{Author details}

${ }^{1}$ The Department of Dermatology, Xiangya Hospital, Central South University, 87 Xiangya Road, Changsha, Hunan, China. ${ }^{2}$ Hunan Key Laboratory of Skin Cancer and Psoriasis, Xiangya Hospital, Central South University, Changsha, Hunan, China. ${ }^{3}$ Hunan Engineering Research Center of Skin Health and Disease, Xiangya Hospital, Central South University, Changsha, Hunan, China. ${ }^{4}$ Department of Dermatology, Affiliated Union Hospital, Tongji Medical College, Huazhong University of Science and Technology, Wuhan, China. ${ }^{5}$ Department of Plastic Surgery of Third Xiangya Hospital, Central South University, Changsha, China.
Received: 25 August 2019 Accepted: 17 January 2020

Published online: 30 January 2020

\section{References}

1. Bu P, Yang P. MicroRNA-203 inhibits malignant melanoma cell migration by targeting versican. Exp Ther Med. 2014;8(1):309-15. https://doi. org/10.3892/etm.2014.1708.

2. Yang P, Bu P, Li C. miR-124 inhibits proliferation, migration and invasion of malignant melanoma cells via targeting versican. Exp Ther Med. 2017;14(4):3555-62. https://doi.org/10.3892/etm.2017.4998.

3. Kong Y, Si L, Zhu Y, Xu X, Corless CL, Flaherty KT, et al. Large-scale analysis of KIT aberrations in Chinese patients with melanoma. Clin Cancer Res. 2011;17(7):1684-91. https://doi.org/10.1158/1078-0432.CCR-10-2346.

4. Long T, Su J, Tang W, Luo Z, Liu S, Liu Z, et al. A novel interaction between calcium-modulating cyclophilin ligand and Basigin regulates calcium signaling and matrix metalloproteinase activities in human melanoma cells. Cancer Lett. 2013;339(1):93-101. https://doi.org/10.1016/j.canle t.2013.07.019.

5. Siegel RL, Miller KD, Jemal A. Cancer statistics, 2017. CA Cancer J Clin. 2017;67(1):7-30. https://doi.org/10.3322/caac.21387.

6. Xu D, Chen X, He Q, Luo C. MicroRNA-9 suppresses the growth, migration, and invasion of malignant melanoma cells via targeting NRP1. Onco Targets Ther. 2016;9:7047-57. https://doi.org/10.2147/OTT.S107235.

7. Traylor JI, Kuo JS. Combined nivolumab and ipilimumab is an effective treatment for melanoma brain metastases. Neurosurgery. 2018. https:// doi.org/10.1093/neuros/nyy619.

8. Bu P, Luo C, He Q, Yang P, Li X, Xu D. MicroRNA-9 inhibits the proliferation and migration of malignant melanoma cells via targeting sirituin 1. Exp Ther Med. 2017;14(2):931-8. https://doi.org/10.3892/etm.2017.4595.

9. Liu N, Wang KS, Qi M, Zhou YJ, Zeng GY, Tao J, et al. Vitexin compound 1, a novel extraction from a Chinese herb, suppresses melanoma cell growth through DNA damage by increasing ROS levels. J Exp Clin Cancer Res. 2018:37(1):269. https://doi.org/10.1186/s13046-018-0897-x.

10. Alves-Fernandes DK, de Oliveira EA, Faiao-Flores F, Alicea-Rebecca G, Weeraratna AT, Smalley KSM, et al. ER stress promotes antitumor effects in BRAFi/MEKi resistant human melanoma induced by natural compound 4-nerolidylcathecol (4-NC). Pharmacol Res. 2018. https://doi. org/10.1016/j.phrs.2018.12.006.

11. Wu CE, Koay TS, Esfandiari A, Ho YH, Lovat P, Lunec J. ATM dependent DUSP6 modulation of p53 involved in synergistic targeting of MAPK and p53 pathways with trametinib and MDM2 inhibitors in cutaneous melanoma. Cancers. 2018. https://doi.org/10.3390/cancers11010003.

12. Bommareddy PK, Aspromonte S, Zloza A, Rabkin SD, Kaufman HL. MEK inhibition enhances oncolytic virus immunotherapy through increased tumor cell killing and T cell activation. Sci Transl Med. 2018. https://doi. org/10.1126/scitranslmed.aau0417.

13. Menzies AM, Ashworth MT, Swann S, Kefford RF, Flaherty K, Weber J, et al. Characteristics of pyrexia in BRAFV600E/K metastatic melanoma patients treated with combined dabrafenib and trametinib in a phase $\mathrm{I} / \mathrm{II}$ clinical trial. Ann Oncol. 2015;26(2):415-21. https://doi.org/10.1093/annonc/ mdu529.

14. Desvignes C, Abi Rached H, Templier C, Drumez E, Lepesant P, Desmedt E, et al. BRAF inhibitor discontinuation and rechallenge in advanced melanoma patients with a complete initial treatment response. Melanoma Res. 2017;27(3):281-7. https://doi.org/10.1097/CMR.0000000000000350.

15. Lee YH, Martin-Orozco N, Zheng P, Li J, Zhang P, Tan H, et al. Inhibition of the B7-H3 immune checkpoint limits tumor growth by enhancing cytotoxic lymphocyte function. Cell Res. 2017;27(8):1034-45. https://doi. org/10.1038/cr.2017.90.

16. Garbe C, Eigentler TK, Keilholz U, Hauschild A, Kirkwood JM. Systematic review of medical treatment in melanoma: current status and future prospects. Oncologist. 2011;16(1):5-24. https://doi.org/10.1634/theon cologist.2010-0190.

17. Longoria TC, Eskander RN. Immune checkpoint inhibition: therapeutic implications in epithelial ovarian cancer. Recent Pat Anticancer Drug Discov. 2015;10(2):133-44.

18. Postow MA. Managing immune checkpoint-blocking antibody side effects. Am Soc Clin Oncol Educ Book. 2015. https://doi.org/10.14694/ edbook_am.2015.35.76. 
19. Mahoney KM, Freeman GJ, McDermott DF. The next immune-checkpoint inhibitors: PD-1/PD-L1 blockade in melanoma. Clin Ther. 2015;37(4):76482. https://doi.org/10.1016/j.clinthera.2015.02.018.

20. Theurich S, Rothschild SI, Hoffmann M, Fabri M, Sommer A, GarciaMarquez $\mathrm{M}$, et al. Local tumor treatment in combination with systemic ipilimumab immunotherapy prolongs overall survival in patients with advanced malignant melanoma. Cancer Immunol Res. 2016;4(9):744-54. https://doi.org/10.1158/2326-6066.CIR-15-0156.

21. Cauwels A, Van Lint S, Garcin G, Bultinck J, Paul F, Gerlo S, et al. A safe and highly efficient tumor-targeted type I interferon immunotherapy depends on the tumor microenvironment. Oncoimmunology. 2018;7(3):e1398876. https://doi.org/10.1080/2162402X.2017.1398876.

22. Yadav VR, Prasad S, Sung B, Aggarwal BB. The role of chalcones in suppression of NF-kappaB-mediated inflammation and cancer. Int Immunopharmacol. 2011;11(3):295-309. https://doi.org/10.1016/j. intimp.2010.12.006.

23. Zhu M, Wang J, Xie J, Chen L, Wei X, Jiang X, et al. Design, synthesis, and evaluation of chalcone analogues incorporate alpha, beta-Unsaturated ketone functionality as anti-lung cancer agents via evoking ROS to induce pyroptosis. Eur J Med Chem. 2018;157:1395-405. https://doi. org/10.1016/j.ejmech.2018.08.072.

24. Bukhari SN, Jasamai M, Jantan I. Synthesis and biological evaluation of chalcone derivatives (mini review). Mini Rev Med Chem. 2012;12(13):1394-403.

25. Singh P, Anand A, Kumar V. Recent developments in biological activities of chalcones: a mini review. Eur J Med Chem. 2014;85:758-77. https://doi.org/10.1016/j.ejmech.2014.08.033.

26. Warmka JK, Solberg EL, Zeliadt NA, Srinivasan B, Charlson AT, Xing C, et al. Inhibition of mitogen activated protein kinases increases the sensitivity of A549 lung cancer cells to the cytotoxicity induced by a kava chalcone analog. Biochem Biophys Res Commun. 2012;424(3):488-92. https://doi.org/10.1016/j.bbrc.2012.06.140.

27. Xu S, Chen M, Chen W, Hui J, Ji J, Hu S, et al. Chemopreventive effect of chalcone derivative, $\mathrm{L} 2 \mathrm{H} 17$, in colon cancer development. BMC Cancer. 2015;15:870. https://doi.org/10.1186/s12885-015-1901-x.

28. Jandial DD, Krill LS, Chen L, Wu C, Ke Y, Xie J, et al. Induction of G2M arrest by flavokawain $\mathrm{A}$, a kava chalcone, increases the responsiveness of HER2-overexpressing breast cancer cells to herceptin. Molecules. 2017. https://doi.org/10.3390/molecules22030462.

29. Chen J, Peng C, Lei L, Zhang J, Zeng W, Chen X. Nuclear envelopedistributed CD147 interacts with and inhibits the transcriptional function of RING1 and promotes melanoma cell motility. PLOS ONE. 2017;12(8):e0183689. https://doi.org/10.1371/journal.pone.0183689.

30. Pelicano H, Carney D, Huang P. ROS stress in cancer cells and therapeutic implications. Drug Resist Updat. 2004;7(2):97-110. https://doi. org/10.1016/j.drup.2004.01.004.

31. Li R, Luo X, Zhu Y, Zhao L, Li L, Peng Q, et al. ATM signals to AMPK to promote autophagy and positively regulate DNA damage in response to cadmium-induced ROS in mouse spermatocytes. Environ Pollut. 2017;231(Pt 2):1560-8. https://doi.org/10.1016/j.envpol.2017.09.044.

32. Zhao H, Piwnica-Worms H. ATR-mediated checkpoint pathways regulate phosphorylation and activation of human Chk1. Mol Cell Biol. 2001;21(13):4129-39. https://doi.org/10.1128/ MCB.21.13.4129-4139.2001.

33. Tu Y, Chen C, Pan J, Xu J, Zhou ZG, Wang CY. The Ubiquitin Proteasome Pathway (UPP) in the regulation of cell cycle control and DNA damage repair and its implication in tumorigenesis. Int J Clin Exp Pathol. 2012;5(8):726-38.

34. Khattak M, Fisher R, Turajlic S, Larkin J. Targeted therapy and immunotherapy in advanced melanoma: an evolving paradigm. Ther Adv Med Oncol. 2013;5(2):105-18. https://doi.org/10.1177/1758834012466280.

35. Paluncic J, Kovacevic Z, Jansson PJ, Kalinowski D, Merlot AM, Huang $\mathrm{ML}$, et al. Roads to melanoma: key pathways and emerging players in melanoma progression and oncogenic signaling. Biochim Biophys Acta. 2016;1863(4):770-84. https://doi.org/10.1016/j.bbamcr.2016.01.025.

36. Margolin K. The promise of molecularly targeted and immunotherapy for advanced melanoma. Curr Treat Options Oncol. 2016;17(9):48. https://doi. org/10.1007/s11864-016-0421-5.

37. Griffin M, Scotto D, Josephs DH, Mele S, Crescioli S, Bax HJ, et al. BRAF inhibitors: resistance and the promise of combination treatments for melanoma. Oncotarget. 2017;8(44):78174-92. https://doi.org/10.18632/ oncotarget.19836.

38. Hatanaka M, Higashi Y, Kawai K, Su J, Zeng W, Chen X, et al. CD147-targeted siRNA in A375 malignant melanoma cells induces the phosphorylation of EGFR and downregulates cdc25C and MEK phosphorylation. Oncol Lett. 2016;1 1(4):2424-8. https://doi.org/10.3892/ol.2016.4267.

39. Fulda S. Modulation of apoptosis by natural products for cancer therapy. Planta Med. 2010;76(11):1075-9. https://doi.org/10.1055/s-0030-1249961.

40. Funakoshi-Tago M, Tanabe S, Tago K, Itoh H, Mashino T, Sonoda Y, et al. Licochalcone A potently inhibits tumor necrosis factor alpha-induced nuclear factor-kappaB activation through the direct inhibition of IkappaB kinase complex activation. Mol Pharmacol. 2009;76(4):745-53. https://doi. org/10.1124/mol.109.057448.

41. Lee JS, Kang Y, Kim JT, Thapa D, Lee ES, Kim JA. The anti-angiogenic and anti-tumor activity of synthetic phenylpropenone derivatives is mediated through the inhibition of receptor tyrosine kinases. Eur J Pharmacol. 2012;677(1-3):22-30. https://doi.org/10.1016/j.ejphar.2011.12.012.

42. Phillips ER, McKinnon PJ. DNA double-strand break repair and development. Oncogene. 2007;26(56):7799-808. https://doi.org/10.1038/ sj.onc.1210877.

43. Zhong G, Chen X, Fang X, Wang D, Xie M, Chen Q. Fra-1 is upregulated in lung cancer tissues and inhibits the apoptosis of lung cancer cells by the P53 signaling pathway. Oncol Rep. 2016;35(1):447-53. https://doi. org/10.3892/or.2015.4395.

44. Tan ZH, Zhang Y, Tian Y, Tan W, Li YH. IkappaB kinase b mediating the downregulation of $\mathrm{p} 53$ and $\mathrm{p} 21$ by lipopolysaccharide in human papillomavirus 16(+) cervical cancer cells. Chin Med J. 2016;129(22):2703-7. https://doi.org/10.4103/0366-6999.193463.

45. Xiao S, Zhou Y, Yi W, Luo G, Jiang B, Tian Q, et al. Fra-1 is downregulated in cervical cancer tissues and promotes cervical cancer cell apoptosis by p53 signaling pathway in vitro. Int J Oncol. 2015;46(4):1677-84. https:// doi.org/10.3892/ijo.2015.2873.

46. Sherr CJ, Roberts JM. CDK inhibitors: positive and negative regulators of G1-phase progression. Genes Dev. 1999;13(12):1501-12.

47. Lei X, Liu B, Han W, Ming M, He YY. UVB-Induced p21 degradation promotes apoptosis of human keratinocytes. Photochem Photobiol Sci. 2010;9(12):1640-8. https://doi.org/10.1039/c0pp00244e.

48. Yang $W$, Tang $H$, Zhang $Y$, Tang $X$, Zhang J, Sun L, et al. Meta-analysis followed by replication identifies loci in or near CDKN1B, TET3, CD80, DRAM1, and ARID5B as associated with systemic lupus erythematosus in Asians. Am J Hum Genet. 2013;92(1):41-51. https://doi.org/10.1016/j. ajhg.2012.11.018.

49. He Y, Yu B. MicroRNA-93 promotes cell proliferation by directly targeting P21 in osteosarcoma cells. Exp Ther Med. 2017;13(5):2003-11. https://doi. org/10.3892/etm.2017.4204.

50. Budanov AV, Shoshani T, Faerman A, Zelin E, Kamer I, Kalinski H, et al. Identification of a novel stress-responsive gene Hi95 involved in regulation of cell viability. Oncogene. 2002;21(39):6017-31. https://doi. org/10.1038/sj.onc.1205877.

51. Fornace AJ Jr, Alamo I Jr, Hollander MC. DNA damage-inducible transcripts in mammalian cells. Proc Natl Acad Sci USA. 1988;85(23):8800-4.

52. Abdollahi A, Lord KA, Hoffman-Liebermann B, Liebermann DA. Sequence and expression of a cDNA encoding MyD118: a novel myeloid differentiation primary response gene induced by multiple cytokines. Oncogene. 1991;6(1):165-7.

53. Zhang W, Bae I, Krishnaraju K, Azam N, Fan W, Smith K, et al. CR6: a third member in the MyD118 and Gadd45 gene family which functions in negative growth control. Oncogene. 1999;18(35):4899-907. https://doi. org/10.1038/sj.onc.1202885.

54. Moskalev AA, Smit-McBride Z, Shaposhnikov MV, Plyusnina EN, Zhavoronkov A, Budovsky A, et al. Gadd45 proteins: relevance to aging, longevity and age-related pathologies. Ageing Res Rev. 2012;11(1):51-66. https ://doi.org/10.1016/j.arr.2011.09.003.

55. Bochman ML, Schwacha A. The Mcm complex: unwinding the mechanism of a replicative helicase. Microbiol Mol Biol Rev. 2009;73(4):652-83. https://doi.org/10.1128/MMBR.00019-09.

56. Das M, Prasad SB, Yadav SS, Govardhan HB, Pandey LK, Singh S, et al. Over expression of minichromosome maintenance genes is clinically correlated to cervical carcinogenesis. PLoS ONE. 2013;8(7):e69607. https://doi. org/10.1371/journal.pone.0069607. 
57. Bailis JM, Forsburg SL. MCM proteins: DNA damage, mutagenesis and repair. Curr Opin Genet Dev. 2004;14(1):17-21. https://doi.org/10.1016/j. gde.2003.11.002.

58. Forsburg SL. Eukaryotic MCM proteins: beyond replication initiation. Microbiol Mol Biol Rev. 2004;68(1):109-31.

59. Mitchel RE, Hasu M, Bugden M, Wyatt H, Hildebrandt G, Chen YX, et al. Low-dose radiation exposure and protection against atherosclerosis in $\mathrm{ApoE}(-/-)$ mice: the influence of P53 heterozygosity. Radiat Res. 2013;179(2):190-9. https://doi.org/10.1667/RR3140.1.

60. Wang H, Luo Y, Zhao MH, Lin Z, Kwon J, Cui XS, et al. DNA double-strand breaks disrupted the spindle assembly in porcine oocytes. Mol Reprod Dev. 2016;83(2):132-43. https://doi.org/10.1002/mrd.22602.

61. Kastan MB, Lim DS. The many substrates and functions of ATM. Nat Rev Mol Cell Biol. 2000;1(3):179-86. https://doi.org/10.1038/35043058.

62. Brown EJ, Baltimore D. Essential and dispensable roles of ATR in cell cycle arrest and genome maintenance. Genes Dev. 2003;17(5):615-28. https:// doi.org/10.1101/gad.1067403.

63. Yin L, Liu Y, Peng Y, Peng Y, Yu X, Gao Y, et al. PARP inhibitor veliparib and HDAC inhibitor SAHA synergistically co-target the UHRF1/BRCA1 DNA damage repair complex in prostate cancer cells. J Exp Clin Cancer Res. 2018;37(1):153. https://doi.org/10.1186/s13046-018-0810-7.
64. Knight M, Raghavan N, Goodall C, Cousin C, Ittiprasert W, Sayed A, et al. Biomphalaria glabrata peroxiredoxin: effect of schistosoma mansoni infection on differential gene regulation. Mol Biochem Parasitol. 2009;167(1):20-31. https://doi.org/10.1016/j.molbiopara.2009.04.002.

65. Moloney JN, Cotter TG. ROS signalling in the biology of cancer. Semin Cell Dev Biol. 2018;80:50-64. https://doi.org/10.1016/j.semcdb.2017.05.023.

66. Mittler R. ROS are good. Trends Plant Sci. 2017;22(1):11-9. https://doi. org/10.1016/j.tplants.2016.08.002.

67. Scialo F, Fernandez-Ayala DJ, Sanz A. Role of mitochondrial reverse electron transport in ROS signaling: potential roles in health and disease. Front Physiol. 2017:8:428. https://doi.org/10.3389/fphys.2017.00428.

\section{Publisher's Note}

Springer Nature remains neutral with regard to jurisdictional claims in published maps and institutional affiliations.
Ready to submit your research? Choose BMC and benefit from:

- fast, convenient online submission

- thorough peer review by experienced researchers in your field

- rapid publication on acceptance

- support for research data, including large and complex data types

- gold Open Access which fosters wider collaboration and increased citations

- maximum visibility for your research: over 100M website views per year

At BMC, research is always in progress.

Learn more biomedcentral.com/submissions 